\title{
Peramalan Nilai Tukar Nelayan Provinsi Sulawesi Tenggara Menggunakan Model Fungsi Transfer Single Input Produksi Perikanan Tangkap
}

\author{
Anton Ari Widodo \\ Badan Pusat Statistik Provinsi Sulawesi Tenggara, antonari@bps.go.id
}

\begin{abstract}
ABSTRAK, Pola Deret Nilai Tukar Nelayan (NTN) di Sulawesi Tenggara menunjukkan pola data musiman, dengan pola pada bulan Oktober hingga Desember menunjukkan nilai indeks tertinggi dibanding bulan-bulan lainnya. Pengaruh jumlah produksi perikanan tangkap yang diperoleh nelayan terhadap indeks NTN ingin diukur menggunakan analisis fungsi transfer. Deret data input maupun output dibagi menjadi data trainer dan data outsampel untuk mengukur sejauh mana model yang dibentuk dari data training mampu meramalkan data out-sampel. Orde fungsi transfer yang diperoleh yaitu $(\mathrm{b}, \mathrm{s}, \mathrm{r}) \mathrm{z}=(1,1,0)$ sehingga model yang terbentuk yaitu $Y_{t}^{\prime}=$ $-0,00015 X_{t-1}{ }^{\prime}+0,00014 X_{t-2}{ }^{\prime}+a_{t}$ dengan residual yang telah whitenoise. Orde model fungsi transfer yang terbentuk mengindikasi bahwa data produksi perikanan tangkap mempengaruhi indeks NTN satu waktu setelahnya (lag-1) dan masih akan terus mempengaruhi nilai indeks NTN dua waktu setelahnya dengan adanya data baru. Hasil peramalan diperoleh bahwa rentang peramalan tidak mampu mencakup nilai aktual indeks NTN yang kemungkinan sangat dipengaruhi oleh adanya intervensi peristiwa Covid-19 pada data outsample.
\end{abstract}

Kata Kunci: Nilai Tukar Nelayan, Produksi
Perikanan Tangkap, Transfer Function,
Sulawesi Tenggara

\section{PENDAHULUAN}

Negara Indonesia adalah negara kepulauan dan $80 \%$ wilayah admintratif provinsinya berbatasan dengan laut atau pesisir pantai. Karakteristik geografis yang terdiri dari beribu pulau membawa keberagaman budaya dan menyimpan kekayaan ekonomi yang unik dibanding negara lainnya [1]. Potensi ekonomi yang terkandung didalamnya sangat besar, 92.2\% produksi perikanan tangkap bersumber dari perikanan tangkap laut dan merupakan sumber penghidupan masyarakat yang bermukin di wilayah pesisir [2]-[4]. Demikian halnya Provinsi Sulawesi Tenggara dengan garis pantai $1.740 \mathrm{Km}$ menempatakan lapangan usaha sektor perikanan sebagai penyumbang nilai Produk Bomestik Regional Bruto (PDRB) terbesar setara dengan sektor pertambangan dengan nilai proporsi sebesar 11,61\%[5]
Meskipun secara umum potensi perikanan di Indonesia merata di wilayah pesisir namun tidak demikian dengan kesejahteraan nelayan perikanan tangkap. Sebahagian besar studi empiris yang dilakukan pada wilayah tertentu dengan pengukuran karakteristik data crosssection (satu titik waktu) menunjukkan kesimpulan bahwa nelayan tangkap adalah suatu komunitas yang lekat dengan kemiskinan dan ketidakberdayaan ekonomi [6]-[9]. Banyak faktor alamiah (musim gelombang laut dan struktur sumber daya alam) dan faktor nonalamiah (keterbatasan akses teknologi tangkap, armada melaut, permodalan dan jaminan sosial) yang menjadi penghambat mengapa nelayan sulit untuk meningkatkan kesejahteraannya.

Secara agregat, Nilai Tukar Nelayan (NTN) biasanya digunakan untuk mengukur tingkat kesejahteraan nelayan. Indikator tersebut dipakai sebagai indikator dini untuk mengukur kesejahteraan nelayan dari sisi kemampuan daya beli yang dipengaruhi oleh jumlah hasil tangkapan, ongkos produksi, harga jual komoditas serta harga barang konsumsi ditingkat perdesaan [10]. Berdasarkan kajian tersebut pemerintah melakukan intervensi peningkatan kesejahteraan nelayan melalui modernisasi alat tangkap khususnya pada nelayan tradisional. Modernisasi alat tangkap diharapkan mampu meningkatkan produktivitasnya sehingga dapat meningkatkan pendapatan dan kesejahteraan nelayan[11].

Penelitian yang mengukur tingkat kesejahteraan nelayan menggunakan indikator agregat melalui deret data time series belum banyak dilakukan. Deret data time series NTN memberikan informasi pola data NTN dalam aspek waktu, sehingga diketahui masa surplus dan masa paceklik dari tingkat kesejahteraan nelayan. Analisis pengaruh jumlah produksi tangkap terhadap NTN dalam suatu deret waktu juga dapat memberikan informasi pada bulan apa indeks NTN mencapai nilai tertinggi. Pengaruh nilai produksi perikanan tangkap terhadap indeks 
NTN akan menggunakan analisis dan teknik peramalan time series. Model time series yang dibentuk akan menggunakan teknik peramalan fungsi transfer.

\section{TINJAUAN PUSTAKA}

\section{Nilai Tukar Nelayan}

Nilai Tukar Nelayan (NTN) atau biasa disebut Nilai Tukar Petani Sub Sektor Perikanan merupakan suatu ukuran parameter yang menunjukkan perbandingan antara indeks yang diterima nelayan (It) dengan indeks yang dibayarkan nelayan (Ib) pada sub sektor perikanan. Indeks NTN menunjukkan apakah tingkat pengeluaran kebutuhan petani sub sektor perikanan dapat dikompensasi dengan pertambahan pendapatan petani dari hasil produksinya. Secara tidak langsung indeks ini menunjukkan tingkat kesejahteraan nelayan tangkap khususnya nelayan tradisional.

\section{Produksi Perikanan Tangkap}

Data Produksi Perikanan Tangkap diperoleh dari data Pelabuhan Pendaratan Ikan (PPI). Pada penelitian kali ini, produksi perikanan dibatasi pada produk ikan hasil tangkap nelayan yang memiliki banyak keterbatasan, diantaranya keterbatasan peralatan tangkap modern, permodalan atau yang biasa kita kenal dengan nelayan tradisional. Data produksi perikanan diperoleh dari pencatatan produksi perikanan tangkap di PPI. Di Indonesia umumnya nelayan tradisional banyak mendaratkan ikannya di pelabuhan-pelabuhan kecil yang tidak menyediakan Tempat Pelelangan Ikan (TPI).

\section{Autoregresisive Integrated Moving Average (ARIMA)}

Proses ARIMA $(p, d, q)$ berarti suatu runtun waktu non stasioner yang setelah diambil selisih lag tertentu atau dilakukan pembedaan menjadi stasioner yang mempunyai model AR derajat $p$ dan MA derajat $q$. Model ARIMA $(p, d, q)$ dinyatakan dalam rumus sebagai berikut[12]:

$$
\emptyset_{\mathrm{p}}(\mathrm{B})(1-\mathrm{B})^{\mathrm{d}} \mathrm{Y}_{\mathrm{t}}=\theta_{0}+\theta_{\mathrm{q}}(\mathrm{B}) \mathrm{a}_{\mathrm{t}}
$$

Model ARIMA yang mengakomodir efek musiman dalam waktu pengamatan $t$ dinotasikan dengan ARIMA $(P, D, Q)^{\mathrm{S}}$ atau SARIMA. Secara umum model SARIMA dapat dituliskan dalam bentuk [12]:

$$
\Phi_{p}\left(B^{S}\right)\left(1-B^{S}\right)^{D} Y_{t}=\Theta_{Q}\left(B^{S}\right) a_{t}
$$

Jika terdapat efek non musiman dan efek musiman dalam model data time series yang dibentuk maka model yang terbentuk adalah model multipikatif yaitu ARIMA $(p, d, q)$ $(P, D, Q)^{\mathrm{S}}$ bentuk umum dari model ARIMA $\left((p, d, q)(P, D, Q)^{\mathrm{S}}\right.$ yaitu

$$
\begin{aligned}
& \phi_{p}(\mathrm{~B}) \Phi_{p}\left(B^{S}\right)(1-B)^{d}\left(1-B^{S}\right)^{D} Y_{t}= \\
& \theta_{q}(B) \Theta_{Q}\left(B^{S}\right) a_{t}
\end{aligned}
$$

\section{Fungsi Transfer}

Secara umum model fungsi transfer dapat ditulis sebagai berikut[13]:

$$
Y_{t}=v(B) X_{t}+\quad t
$$

Dimana :

$Y_{t} \quad$ : Deret Output

$v(B)$ : Fungsi bobot respon impuls, biasanya ditulis dengan

$$
v(B)=\left(v_{0}+v_{1} B+v_{2} B^{2}+\cdots+v_{k} B^{k}\right)
$$

Dimana $\mathrm{k}$ adalah orde fungsi transfer, $v_{k}$ adalah bobot respon impuls pada lag $\mathrm{k}$ dan $\mathrm{B}$ adalah operator mundur

$X_{t}$ : Deret input

$n_{t}$ : Pengaruh kombinasi dari seluruh faktor yang mempengaruhi $Y_{t}$ dan disebut dengan gangguan, noise.

Orde fungsi orde fungsi transfer adalah $\mathrm{k}$ akan menjadi orde tertinggi untuk proses pembedaan [13] sehingga, model fungsi transfer dapat dituliskan dalam model sebagai berikut :

$$
\begin{gathered}
Y_{t}=\frac{\omega_{s}(B) B^{b}}{\delta_{r}(B)} X_{t}+n_{t} \\
Y_{t}=\frac{\omega_{s}(B) B^{b}}{\delta_{r}(B)} X_{t}+\frac{\theta(B)}{\phi(B)} a_{t}
\end{gathered}
$$

Dimana :

$\omega_{s}(B)=\omega_{0}-\omega_{1} B-\omega_{2} B^{2}-\cdots-\omega_{s} B^{r}$

$\delta_{r}(B)=1-\delta_{1} B-\delta_{2} B^{2}-\cdots-\delta_{r} B^{r}$

$\theta(B)=1-\theta_{1} B-\theta_{2} B^{2}-\cdots-\theta_{q} B^{q}$

$\phi(B)=1-\phi_{1} B-\phi_{2} B^{2}-\cdots-\phi_{p} B^{p}$

$Y_{t}=$ Nilai deret output yang telah ditransformasikan dan dibedakan 
$X_{t} \quad$ : Nilai deret input yang telah ditransformasikan dan dibedakan

$a_{t}$ : Nilai gangguan (noise) random

$(b, s, r)$ adalah orde fungsi transfer dan $(p, q)$ adalah orde ARIMA residual fungsi transfer

\section{Estimasi Parameter dan Diagnose Checking}

Setelah mengidentifikasi model tentatif timeseries yang dibentuk, langkah selanjutnya adalah menentukan nilai estimasi parameter yang secara umum mengikuti model ARIMA $(p, q)$ atau SARIMA $(p, q)(P, Q)$. Pada deret data timeseries, estimasi parameter menggunakan beberapa metode yakni Metode Moment, Metode Maximum Likelihood, Estimasi Parameter Non Linier, Estimasi Ordinary Least Square (OLS) pada deret data timeseries [12]. Khusus pada penelitian ini, estimasi parameter menggunakan metode Maximum Likelihood dengan memaksimumkan nilai peluang fungsi bersama (joint probability density) dari parameter $\left(\phi, \mu, \theta, \sigma^{2}\right)$ deret data series dengan asumsi residual pada model tentative yang terbentuk berdistribusi Normal $\left(0, \sigma_{a}^{2}\right)$ whitenoise.

Langkah selanjutnya yaitu seleksi model terbaik (Diagnose Checking) dengan membandingkan nilai residual terkecil melalui perhitungan nilai Akaike Information Criterion (AIC), atau Scharz Bayesian Criterion (SBC) terkecil sebagai model terbaik [14] .

\section{METODOLOGI}

Penelitian ini memakai metode kuantitatif dengan menggunakan deret output yaitu Nilai Tukar Nelayan (NTN). NTN digunakan sebagai variabel pendekatan untuk mengukur tingkat kesejahteraan nelayan, khususnya nelayan tradisional. Adapun deret input yaitu produksi perikanan yang bersumber dari pencatatan data produksi Pangkalan Pendaratan Ikan (PPI). Kedua data tersebut masing-masing bersumber dari data Badan Pusat Statistik (BPS) Provinsi Sulawesi Tenggara yang dikumpulkan sejak tahun 2014-2020 setiap bulannya. Alat analisis yang digunakan pada penelitian ini adalah Fungsi Transfer. Deret data yang digunakan akan dibagi menjadi dua, yaitu Deret Data In-Sampel (20142019) dan Deret Data Out-Sampel 2020. Deret data in-sampel akan digunakan untuk menentukan model Fungsi Transfer terbaik dalam meramalkan indeks NTN beberapa waktu kedepannya.

\section{Prosedur Analisis}

Penelitian ini menggunakan software SAS University Edition dan Minitab 16 dalam proses pengolahan data. Tahapan dalam membentuk model time series dari data input dan output yaitu:

1. Mengidentifikasi bentuk model fungsi transfer melalui tahapan berikut:

a. Pre-whitening deret input; membentuk model ARIMA untuk data input melalui tahapan identifikasi model, estimasi parameter model, dan pengujian model sehingga mendapatkan nilai prewhitening deret input.

b. Pre-whitening deret output.

c. Perhitungan cross correlation deret input dan output yang telah melalui proses pre-whitening.

d. Penetapan $(b, r, s)$ model fungsi transfer.

e. Estimasi parameter model fungsi transfer.

f. Perhitungan deret noise $n_{t}$ dari fungsi transfer.

g. Penetapan $\left(p_{n}, q_{n}\right)$ untuk model ARIMA $\left(p_{n}, 0, q_{n}\right)$ dari deret noise $n_{t}$.

2. Melakukan uji diagnosis model fungsi transfer yang terbentuk.

3. Penetapan model fungsi transfer dari data series input dan output yang sesuai.

\section{PEMBAHASAN}

\section{Data Produksi Perikanan Tangkap}

Sepanjang tahun 2014-2020, data produksi perikanan tangkap di Sulawesi Tenggara sangat bervariasi namun tetap menunjukkan suatu pola data musiman. Pola data musiman tersebut tergambar dari plot grafik time series data yang berulang pada bulan-bulan tertentu seperti ratarata produksi perikanan tangkap pada bulan 
Oktober adalah tertinggi dibanding bulan-bulan lainnya sebesar 605.597 Ton. Puncak produksi perikanan tangkap pada series data yaitu bulan Oktober 2017 total produksi sebesar 822.210 Ton disusul produksi tertinggi kedua yaitu masih di tahun yang sama pada bulan September sebesar 764.579 Ton serta di tahun berikutnya, 2018, dibulan Oktober sebesar 756.300 Ton. Hal ini sesuai dengan fenomena alam, dimana pada bulan tersebut musim angin menjadi faktor pendukung tingkat produksi perikanan tangkap di Sulawesi Tenggara.

Musim angin timur (angin teduh) yang berhembus pada bulan Agustus-Oktober menjadi penentu mengapa dibulan-bulan tersebut puncak produksi perikanan tangkap memberikan hasil yang lebih memuaskan dibanding bulan-bulan lainnya di tahun yang sama. Hal sebaliknya terjadi ketika musim angin barat yang berhembus di sekitar bulan April - Juni, produksi perikanan tangkap nelayan menuju titik paling rendah pada setiap tahunnya dengan rata-rata produksi 362.784 Ton. Khusus untuk wilayah perairan Sulawesi Tenggara, angina yang berhembus pada bulan April - Juni menyebabkan gelombang tinggi yang mampu mencapai $2,5-3$ meter.

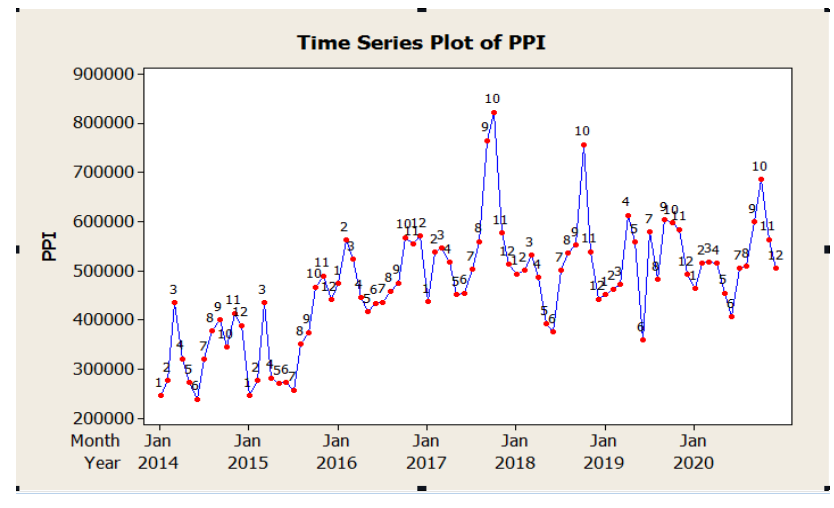

Gambar 1 Pola Series Data Perikanan Tangkap Sulawesi Tenggara Tahun 2014-2020

\section{Indeks NTN}

Series data NTN Sulawesi Tenggara cukup berfluktuatif dan cenderung memiliki pola trend meskipun terdapat pola musiman di bulan-bulan tertentu. Tercatat indeks NTN dibulan September 2019 tertinggi sebesar 119,45 dan indeks terendah tercatat pada bulan April 2020 sebesar 95,12 poin. Rendahnya rata-rata indeks NTN di Sulawesi Tenggara dibawah 100 memberikan informasi bahwa di bulan tersebut, nilai pendapatan nelayan lebih rendah dibandingkan nilai rupiah yang harus dikeluarkan untuk biaya hidup dan modal produksi.

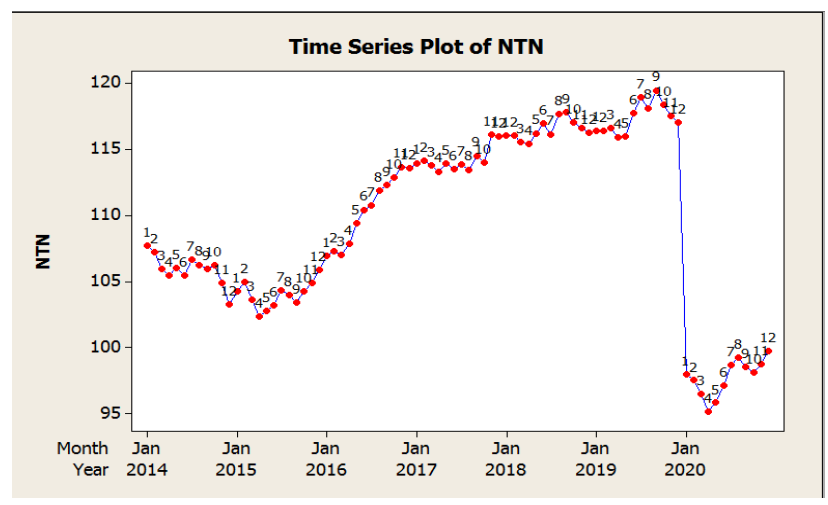

Gambar 2 Pola Series Indeks NTN Sulawesi Tenggara Tahun 2014-2020

Series data indeks NTN di tahun 2020 di Sulawesi Tenggara terendah dibanding pada bulan yang sama ditahun-tahun sebelumnya. Rendahnya indeks tersebut bukan hanya disebabkan oleh rendahnya nilai produksi tangkap nelayan sebagai akibat Pembatasan Sosial Berskala Besar (PSBB) namun juga disebabkan oleh rendahnya harga beli atas produk perikanan nelayan. Di tahun 2020 daya beli masyarakat yang mengkonsumsi produk perikanan sangat rendah, hal ini disebabkan oleh dampak ekonomi covid-19 yang berkepanjangan dan mengancam mata pencaharian masyarakat non-nelayan.

\section{Penentuan Model SARIMA Deret Input}

Jika merujuk pada plot data time series deret input maka diperoleh gambaran bahwa data belum stasioner dan cenderung membentuk pola musiman. Asumsi dasar yang harus dipenuhi dalam analisis time series adalah data harus stasioner dalam varians maupun dalam rata-rata. Pemeriksaan asumsi apakah deret input telah stasioner dalam varian dapat melalui uji BoxCox plot.

Gambar 3 menunjukkan nilai $\lambda$ telah bernilai 1 dan dapat diasumsikan bahwa data telah stasioner dalam varians. Pemeriksaan kestasioneran data dalam rata-rata dapat dilakukan dengan menggunakan plot ACF dan PACF atau nilai uji statistik Dickey Fuller Test. Hasil uji statistik Dickey Fuller Test menunjukkan nilai $p$-value $>0,05$ (taraf uji statistik) sehingga disimpulkan bahwa data 
produksi perikanan PPI masih belum stasioner dalam rata-rata. Deret data masih perlu dilakukan differencing (pembedaan) pada lag 1 .

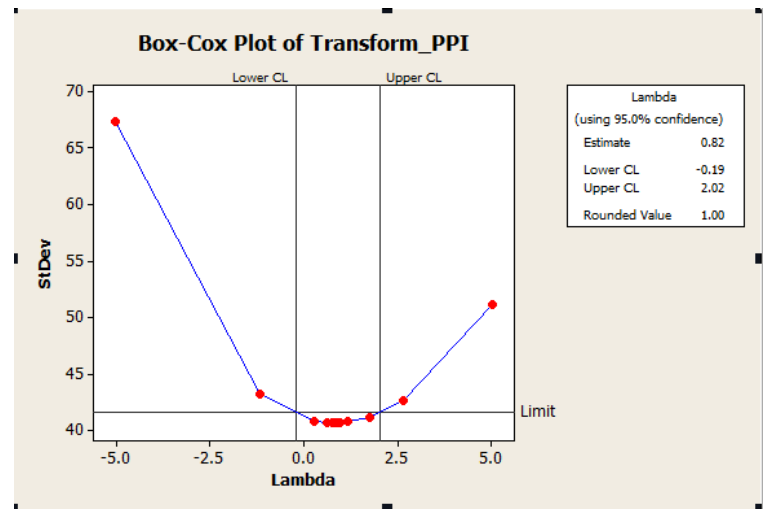

Gambar 3 Box-Cox Plot Transformasi Deret Input

Uji statistik Dickey Fuller Test kembali dilakukan dengan data yang telah differencing lag-1 dan menghasilkan uji statistik dimana nilai $p$-value $<0,05$ atau data telah stasioner dalam rata-rata. Pada Gambar 4 menunjukkan bahwa pola data telah stasioner baik dalam varians maupun rata-rata, dimana pola PACF dan ACF yang cenderung cut-off pada lag-lag tertentu.
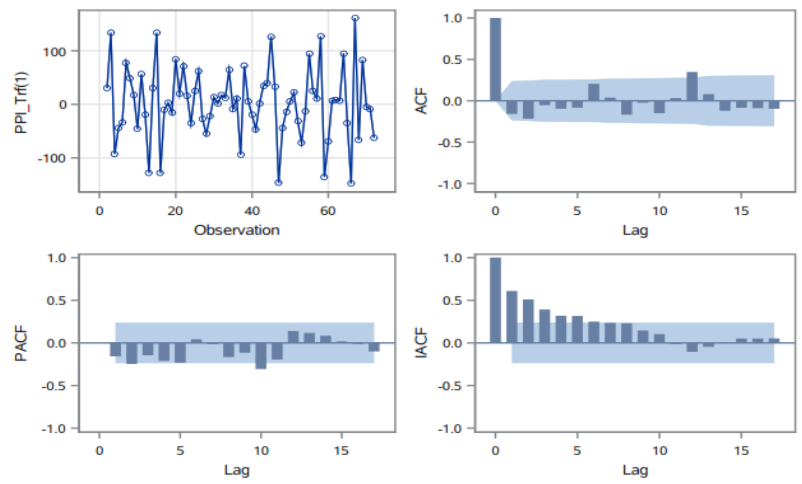

Gambar 4 Pola ACF dan PACF ) setelah proses differencing pada lag -1

Berdasarkan Gambar 4 diperoleh beberapa kemungkinan ordo fungsi ARIMA yang signifikan pada plot lag ACF dan PACF. Hasil identifikasi lag yang signifikan diperoleh kemungkinan model ARIMA PPI ARIMA $(1,1,0)(1,0,0)^{12},(1,1,1)(1,0,0)^{12}$,

$(0,1,1)(1,0,0)^{12}$. Estimasi parameter model ARIMA menurut metode Maximum likelihood diperoleh seluruh parameter kemungkinan model ARIMA signifikan. Penentuan model terbaik yang dapat menjelaskan pola data deret waktu produksi perikanan PPI ditentukan melalui nilai residual model terkecil. Sehingga dapat diambil kesimpulan bahwa model ARIMA $(1,1,0)(1,0,0)^{12}$ adalah model terbaik dengan nilai residual model terkecil serta memenuhi asumsi residual yang white-noise. Model ARIMA $(1,0,0)(1,1,0)^{\mathrm{s}}$ dengan deret input data produksi perikanan PPI dinyatakan dalam persamaan sebagai berikut :

$$
\left(1-\emptyset_{1} B\right)\left(1-\Phi_{1} B^{12}\right)(1-B) X_{t}^{\prime}=a_{t}
$$

Dimana $X_{t}^{\prime}=\sqrt{X_{t}}$ merupakan notasi transformasi deret input data produksi perikanan PPI yang telah stasioner dalam ragam.

Tabel 1. Hasil Uji Signifikansi Parameter Model Data Produksi Perikanan PPI

\begin{tabular}{lcccl}
\hline $\begin{array}{l}\text { Model Tentatif } \\
\text { ARIMA }\end{array}$ & $\begin{array}{l}\text { Para- } \\
\text { meter }\end{array}$ & $\begin{array}{l}\text { Esti- } \\
\text { masi }\end{array}$ & $\begin{array}{l}p- \\
\text { Value }\end{array}$ & $\begin{array}{l}\text { Ke- } \\
\text { putu } \\
\text { san }\end{array}$ \\
\hline$(1,1,0)(1,0,0)^{12}$ & $\phi$ & -0.280 & 0,0138 & Sig \\
& $\Phi$ & 0,525 & $<, 0001$ & Sig \\
$(1,1,1)(1,0,0)^{12}$ & $\phi$ & 0,413 & 0,0069 & Sig \\
& $\Phi$ & 0,494 & $<, 0001$ & Sig \\
& $\theta$ & 0,869 & $<, 0001$ & Sig \\
$(0,1,1)(1,0,0)^{12}$ & $\Phi$ & 0,548 & $<, 0001$ & Sig \\
& $\theta$ & 0,550 & $<, 0001$ & Sig \\
\hline
\end{tabular}

Model ARIMA $(1,1,0)(1,0,0)^{12}$ menunjukkan bahwa pola deret waktu data produksi perikanan PPI memliki orde model ARIMA komponen AR atau Autoregresive $(\mathrm{p}=1)$ dan komponen musiman $(\mathrm{P}=1)$. Hal ini menunjukkan bahwa pola data waktu ke-t data produksi perikanan PPI sangat dipengaruhi pola data waktu ke t-1 atau satu waktu sebelumnya serta waktu t-12 atau komponen pola data musiman satu tahun sebelumnya. Model tersebut sejalan pola produksi perikanan tangkap di Sulawesi Tenggara yang dipengaruhi oleh pola gelombang laut (musim angin timur/musim angin barat/pancaroba) satu bulan sebelumnya dan terkoreksi dengan pola musiman tangkap satu tahun sebelumnya. Gelombang laut menjadi faktor alamiah yang berpengaruh besar dalam 
menentukan besaran nilai pendapatan nelayan tangkap di bulan tersebut

\section{Proses Pre-Whitening Deret Input dan Output}

Pre-Whitening (Pemutihan) deret input merupakan suatu proses yang bertujuan unutk menghilangkan pengaruh-pengaruh lain sehingga terbentuk deret yang bersifat white noise. Proses Pre-Whitening deret input dilakukan dengan mengkonversi deret input stasioner menjadi white noise. Jika model ARIMA deret input produksi PPI adalah ARIMA $(1,1,0)(1,0,0)^{12}$ dengan persamaan :

$$
\begin{aligned}
& \left(1+0.2804 B^{1}\right)\left(1-0.52598 B^{12}\right) \\
& (1-B) X^{\prime}=a_{t} \\
& \begin{aligned}
X_{t}{ }^{\prime}=X_{t-1}{ }^{\prime}+ & \phi_{1}\left(X_{t-1}{ }^{\prime}-X_{t-2}{ }^{\prime}\right) \\
& +\Phi_{1}\left(X_{t-12}{ }^{\prime}-X_{t-13}{ }^{\prime}\right) \\
& -\phi_{1} \Phi_{1}\left(X_{t-13}{ }^{\prime}-X_{t-14}\right) \\
& +a_{t}
\end{aligned}
\end{aligned}
$$

Atau

$$
\begin{aligned}
X_{t}{ }^{\prime}=X_{t-1}{ }^{\prime}- & 0,2804\left(X_{t-1}{ }^{\prime}-X_{t-2}{ }^{\prime}\right) \\
& +0,5259\left(X_{t-12}{ }^{\prime}-X_{t-13}{ }^{\prime}\right) \\
& -0,1474\left(X_{t-13}{ }^{\prime}-X_{t-14}{ }^{\prime}\right)+
\end{aligned}
$$

Sehingga model pemutihan untuk deret input data produksi PPI adalah :

$$
\begin{array}{r}
a_{t}=X_{t}{ }^{\prime}-X_{t-1}{ }^{\prime}+0,2804\left(X_{t-1}{ }^{\prime}-X_{t-2}{ }^{\prime}\right) \\
-0,5259\left(X_{t-12}{ }^{\prime}-X_{t-13}{ }^{\prime}\right) \\
+0,1474\left(X_{t-13}{ }^{\prime}-X_{t-14}\right)
\end{array}
$$

Proses Pre-Whitening deret output bertujuan untuk memetakan deret input dalam deret output dan tidak harus menghasilkan deret yang bersifat white noise karena proses Pre-Whitening deret output disesuikan dengan model ARIMA dari deret input dengan mengkonversikan deret output $Y_{t}$ dan $\beta_{t}$.

Model Pre-Whitening deret output NTN berdasarkan deret input data produksi perikanan PPI yaitu :

$$
\begin{array}{r}
\beta_{t}=Y_{t}{ }^{\prime}-Y_{t-1}{ }^{\prime}+0,2804\left(Y_{t-1}{ }^{\prime}-Y_{t-2}{ }^{\prime}\right) \\
-0,5259\left(Y_{t-12}{ }^{\prime}-Y_{t-13}{ }^{\prime}\right) \\
+0,1474\left(Y_{t-13}{ }^{\prime}-Y_{t-14}\right)
\end{array}
$$

\section{Identifikasi Deret Noise dan Uji Diagnosis}

Berdasarkan output plot CrossCorrelation (CCF) diperoleh orde (b,r,s) fungsi transfer yaitu $\mathrm{b}=1, \mathrm{~s}=1$ dan $\mathrm{r}=0$. Identifikasi ini mengindikasi bahwa data produksi perikanan PPI mempengaruhi indeks NTN satu waktu setelahnya (Lag-1) dan masih akan terus mempengaruhi nilai indeks NTN setelah ada data baru satu waktu setelahnya.

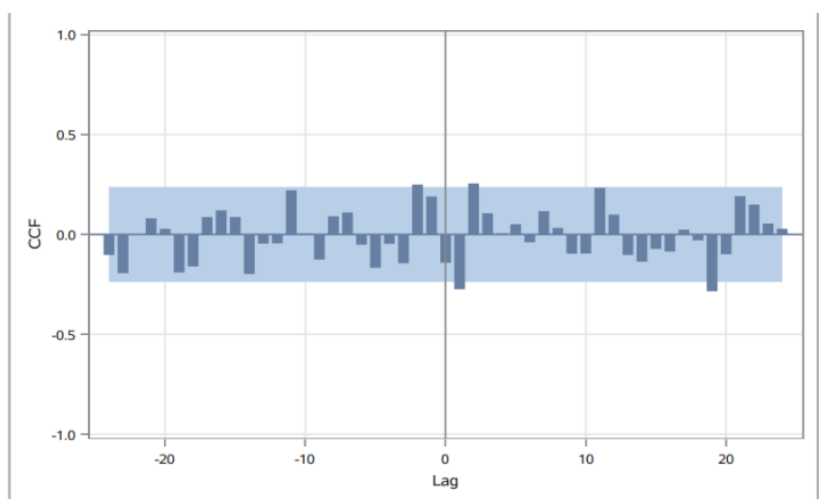

Gambar 5. Pola CCF Deret Input dan Deret Output

Hasil kajian oleh LIPI menunjukkan bahwa penentuan harga produk perikanan tangkap serta pemasaran oleh nelayan tangkap di Sulawesi Tenggara masih dikuasai oleh beberapa pihak pemodal besar. Sistem penentuan harga di TPI (Fempat Pelelangan Ikan) di Sulawesi tenggara masih harus menunggu ketetapan harga oleh pembeli di luar kota khususnya di Provinsi Sulawesi Selatan. Akibatnya nelayan tidak bisa langsung menikmati hasil produksi tangkap mereka.

\section{Estimasi parameter fungsi transfer}

Tabel 2. Uji Signifikansi Parameter Model Awal Fungsi Transfer Terhadap Indeks NTN

\begin{tabular}{lllll}
\hline $\begin{array}{l}\text { Orde } \\
(b, s, r)\end{array}$ & $\begin{array}{l}\text { Para- } \\
\text { meter }\end{array}$ & Es-timasi & $\begin{array}{l}p \text { - } \\
\text { Value }\end{array}$ & $\begin{array}{l}\text { Ke- } \\
\text { putusan }\end{array}$ \\
\hline \multirow{2}{*}{$(1,1,0)$} & $\omega_{01}$ & $-0,00015$ & 0,0361 & Sig \\
& $\omega_{11}$ & $-0,00014$ & 0,0503 & Sig
\end{tabular}

Tabel 2 menunjukkan hasil uji signifikansi Parameter Model Awal Fungsi Transfer terhadap indeks NTN di Sulawesi Tenggara sejak tahun 2014-2019. Merujuk pada tabel tersebut maka model fungsi transfer yang terbentuk yaitu:

$$
Y_{t}^{\prime}=\left(\omega_{01}-\omega_{11} B\right) B^{b} X_{t}^{\prime}+\eta_{t}
$$




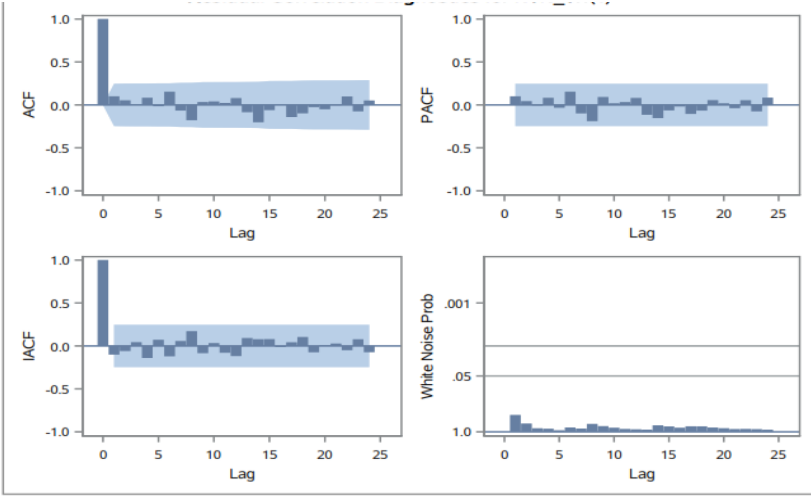

Gambar 6. Plot ACF PACF atas residual model fungsi transfer Data Produksi Perikanan PPI terhadap NTN $(1,1,0)$

Sebelum melakukan peramalan deret output, terlebih dahulu dilakukan pemodelan ARIMA atas residual model yang terbentuk (deret noise $\eta_{t}$ ). Terlihat pada gambar 6 bahwa residual model fungsi transfer telah white noise sehingga tidak ada model ARIMA yang terbentuk atas residual model. Hasil uji normalitas residual dengan uji KolmogorovSmirnov juga diperoleh nilai p_Value $<0,10$ sehingga dapat disimpulkan bahwa residual dari model fungsi transfer telah berdistribusi normal. Dengan demikian model final atas fungsi transfer yang terbentuk adalah :

$$
\begin{gathered}
Y_{t}^{\prime}=\left(\omega_{01}-\omega_{11} B\right) B^{b} X_{t}{ }^{\prime}+a_{t} \\
\text { atau } \\
Y_{t}^{\prime}=-0,00015 X_{t-1}{ }^{\prime}+0,00014 X_{t-2} \\
+a_{t}
\end{gathered}
$$

\section{Identifikasi Deret Noise dan Uji Diagnosis}

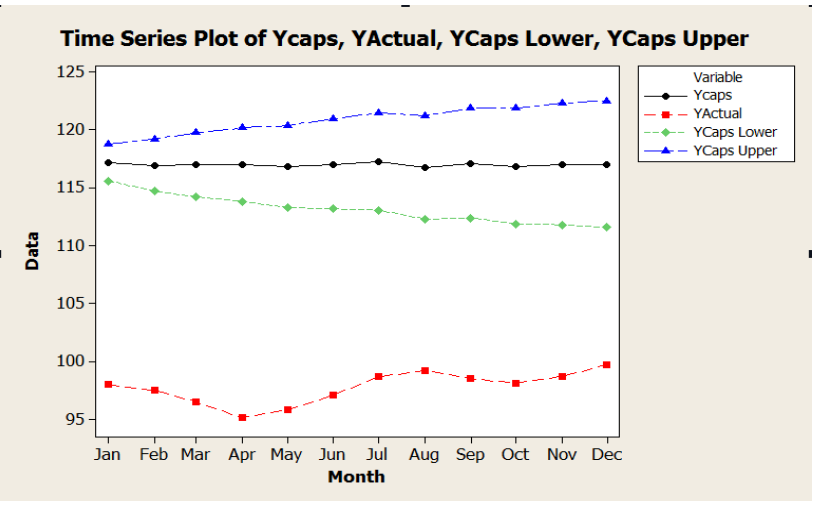

Gambar 7 Perbandingan Plot Timeseries Ramalan k=12 Model Fungsi Transfer dan Data Aktual NTN
Gambar 7 menunjukkan hasil peramalan model fungsi transfer $(1,1,0)$ data produksi perikanan PPI terhadap NTN untuk bulan Januari Desember 2020. Hasil peramalan menunjukkan pola data yang berfluktuasi setiap bulannya, dimana hasil peramalan indeks NTN tertinggi terjadi pada bulan Juli sebesar 117.25 dan indeks terendah terjadi pada bulan Agustus sebesar 116.74. Jika kita membandingkan plot data peramalan 12 bulan kedepan dengan data aktualnya, terlihat pada Gambar 7 nilai peramalan jauh diatas nilai indeks NTN sebenarnya.

Pada Gambar 7 memperlihatkan nilai data aktual tidak berada pada rentang nilai estimasi model fungsi transfer input data produksi perikanan PPI terhadap Indeks NTN. Hal ini kemungkinan besar dipengaruhi oleh adanya intervensi peristiwa Covid-19 di tahun 2020, dimana faktor pendapatan nelayan tidak mutlak dipengaruhi oleh besaran jumlah hasil tangkap namun juga dipengaruhi oleh daya beli masyarakat terhadap produk perikanan.

\section{KESIMPULAN}

\section{Model ARIMA $(1,1,0)(1,0,0)^{12}$} menunjukkan pola deret data produksi perikanan PPI waktu ke- $t$ (saat ini) dipengaruhi oleh pola data waktu ke t-1 atau satu waktu sebelumnya serta waktu t-12 atau komponen pola data musiman satu tahun sebelumnya. Model yang terbentuk secara tepat meramalkan nilai dua belas bulan kedepan. Adapun Model Fungsi Transfer yang terbentuk oleh deret input data produksi perikanan PPI terhadap Indeks NTN adalah $(b=1, s=1, r=0)$. Hasil peramalan belum dapat menggambarkan data aktual indeks NTN di tahun 2020. Rekomendasi dari penelitian ini adalah penentuan model peramalan yang dapat menggambarkan pola data Indeks NTN kedepannya perlu memasukan efek intervensi atas adanya schock yang terjadi pada rentang waktu penelitian, misalnya pengaruh terjadinya pandemi Covid-19.

\section{DAFTAR PUSTAKA}

[1] Yonvitner, "Produktivitas Nelayan, Kapal 
dan Alat Tangkap di Wilayah Pengelolaan Perikanan Indonesia," J. Perikan., vol. IX, no. 1, pp. 254-266, 2007.

[2] A. et. a. Suman, "Potensi dan Tingkat Pemanfaatan Sumberdaya Ikan di Wilayah Pengelolaan Perikanan Republik Indonesia ( WPP NRI ) Tahun 2015 Serta Opsi Pengelolaanya," J. Kebijak. Perikan. Indones., vol. 8, no. 021, pp. 97-110, 2016.

[3] R. Noviyanti, "Peran penyuluh bagi nelayan di kelurahan palabuhanratu kabupaten sukabumi," vol. 45, no. 2, pp. 96-102, 2017.

[4] Tursilarini, "Meningkatkan Kesejahteraan Sosial Nelayan Tradisional di Desa Arungkeke," J. Penelit. dan Pengemb. Kesejaht. Sos., vol. 16, pp. 53-68, 2011.

[5] P. S. T. BPS, Sulawesi Tenggara Dalam Angka 2020, Pertama. Kendari: UD Resky Bersama.

[6] G. Goso and S. M. Anwar, "Kemiskinan Nelayan Tradisional Serta Dampaknya Terhadap Perkembangan Kumuh," J. Manaj. STIE Muhammadiyah Palopo, vol. 3, no. 1, pp. 25-37, 2017, doi: 10.35906/jm001.v3i1.201.

[7] Z. C. S. A. Farisa, "Analisis Faktor-Faktor Yang Mempengaruhi Peningkatan Pendapatan Keluarga nelayan di Pasi Lhok Kembang Tanjong," J. Ilm. Mhs. Kelaut. dan Perikan. Unsyiah, vol. 2, pp. 169-174, 2017.

[8] Y. Zebua, P. K. Wildani, A. Lasefa, and R. Rahmad, "Faktor Penyebab Rendahnya Tingkat Kesejahteraan Nelayan Pesisir Pantai Sri Mersing Desa Kuala Lama Kabupaten Serdang Bedagai Sumatera Utara," J. Geogr., vol. 9, no. 1, p. 88, 2016, doi: 10.24114/jg.v9i1.6923.

[9] D. Vibriyanti, "Analisis Deskpriptif Faktor Sosial Ekonomi yang Mempengaruhi Pendapatan Rumah Tangga Nelayan Tangkap (Studi Kasus: Kota Kendari)," J. Kebijak. Sos. Ekon. Kelaut. dan Perikan., vol. 9, no. 1, p. 69, 2019, doi: 10.15578/jksekp.v9i1.7440.

[10] Ministry of Marine Affairs and Fisheries Republic of Indonesia, Laporan Kinerja Kementrian Kelautan dan perikanan
2017, Edisi 4 (R. Jakarta: Kementrian Kelautan dan Perikanan, 2018.

[11] Kementerian Kelautan dan Perikanan, "Kepala PPS Kendari Dampingi Walikota Kendari Saat Penyerahan Bantuan Kapal Perikanan dan Asuransi Nelayan Kepada Nelayan Kota Kendari.” .

[12] W. W. . Wei, Time Series Analysis Univariate dan Multivariate Methods), 2nd ed. Newyork: Perason Addsison Wesley, Inc., 2006.

[13] H. R. Makridakis S, Wheelwright SC, Forecasting: Methods and Application (3nd Edition), 3nd ed. Newyork: Wiley, 1997.

[14] Rakmawan, Sapto, "Peramalan Ekspor Minyak Kelapa Sawit Indonesia Menggunakan Model ARIMA", Jurnal Matematika dan Statistika Serta Aplikasi, Vol 7, No 2 Juli-Des 2019. 